\title{
Liming as a means of reducing copper toxicity in black oats
}

\author{
Jucinei José Comin ${ }^{*}$ Vítor Gabriel Ambrosini ${ }^{1}$ Daniel José Rosa ${ }^{2}$ Alex Basso ${ }^{1} C_{0}$ \\ Arcângelo Loss $^{1}$ George Wellington Bastos de Melo ${ }^{3}$ Paulo Emílio Lovato ${ }^{1}$ \\ Cledimar Rogério Lourenzi ${ }^{1}$ Felipe Klein Ricachenevsky ${ }^{4}$ Gustavo Brunetto $^{5}$
}

1Departamento de Engenharia Rural, Centro de Ciências Agrárias, Universidade Federal de Santa Catariana (UFSC), Rod. Admar Gonzaga,
1346, Itacorubi, 88034.001, Florianópolis, SC, Brasil. E-mail: j.comin@ufsc.br. "Corresponding author.
${ }^{2}$ Departamento de Fitotecnia, Centro de Ciências Agrárias, Universidade Federal de Santa Catariana (UFSC), Florianópolis, SC, Brasil.
${ }^{3}$ Empresa Brasileira de Pesquisa Agropecuária, Embrapa Uva e Vinho, Bento Gonçalves, RS, Brasil.
${ }^{4}$ Departamento do Biologia, Universidade Federal de Santa Maria (UFSM), Santa Maria, RS, Brasil.
${ }^{5}$ Departamento de Solos, Universidade Federal de Santa Maria (UFSM), Santa Maria, RS, Brasil.

ABSTRACT: Soils which are cultivated with grapevines have high available copper (Cu) content, which can be toxic to cover crops cohabiting vineyards, such as black oats. This study aimed to assess the effect of liming in reducing Cu toxicity in black oats grown in sandy soils. Samples of a Typic Hapludalf were collected at $0-20 \mathrm{~cm}$, dried and subjected to the addition of Cu (0 to $\left.50 \mathrm{Mg} \mathrm{kg}^{-1}\right)$ and limestone $(0,1.5$, and $3.0 \mathrm{Mg}$ $\left.h \mathrm{a}^{-1}\right)$. The soil was placed in a rhizobox and black oats were grown for 30 days. We assessed root and shoot dry matter production, copper (Cu), calcium (Ca) and magnesium (Mg) contents in the tissues; $\mathrm{Cu}$ content in the root symplast and apoplast, as well as $\mathrm{Cu}$, carbon and $\mathrm{pH}$ values in the rhizosphere and bulk soil. Liming reduced Cu toxicity in black oats. $\mathrm{Cu}$ was preferentially accumulated in the roots, mostly in the apoplast, which may be the result of a plant tolerance mechanism to prevent the transport of Cu to the shoots.

Key words: heavy metal, phytotoxicity, limestone, rhizosphere.

Calagem como forma de redução da toxidez por cobre em aveia preta

RESUMO: Solos cultivados com videiras possuem alto teor de cobre (Cu) disponível, que pode ser tóxico às plantas de cobertura do solo que coabitam vinhedos, como a aveia preta. O estudo objetivou avaliar o efeito da calagem na redução da toxidez por Cu em plantas de aveia preta cultivadas em solo arenoso. Amostras de um Argissolo Vermelho foram coletadas na camada de 0-20cm, secas e submetidas à adição de duas doses de Cu $\left(0\right.$ e $\left.50 \mathrm{Mg} \mathrm{kg}^{-1}\right)$ e três de calcário $(0,1,5$ e 3,0Mg ha-1). O solo foi acondicionado em rhizobox e submetido ao cultivo de aveia preta durante 30 dias. Avaliaram-se a produção de matéria seca das raízes e da parte aérea, o teor de cobre (Cu), cálcio (Ca) e magnésio (Mg) nos tecidos; o teor de Cu no simplasto e apoplasto das raizes, e os teores de Cu, de carbono e valores de pH no solo rizosférico e não rizosférico. A aplicação de calcário reduziu a toxidez por Cu na aveia preta. O Cu foi preferencialmente acumulado nas raizes, especialmente no apoplasto, o que pode ser resultado de mecanismo de tolerância das plantas para evitar o transporte de parte do elemento para a parte aérea.

Palavras-chave: metal pesado, fitotoxidez, calcário, rizosfera.

\section{INTRODUCTION}

The frequent application of copper-based $(\mathrm{Cu})$ fungicides, such as Bordeaux mixture $\left(\mathrm{Ca}(\mathrm{OH})_{2}\right.$ $\left.+\mathrm{CuSO}_{4}\right)$, for the preventive control of foliar fungal diseases in grapevines (Vitis sp.) causes the increase of the $\mathrm{Cu}$ content in vineyard soils, especially in topsoil. In the soil, $\mathrm{Cu}$ may be complexed by soil organic matter (SOM) and sorbed by iron (Fe), aluminum (Al) and manganese (Mn) oxides and clay minerals, through physicochemical bonds in which the binding energy of $\mathrm{Cu}$ depends on soil $\mathrm{pH}$ and on the nature of the ligand (MICHAUD et al., 2007, CASALI et al., 2008). Therefore, increased $\mathrm{Cu}$ in the soil may increase the amount of more labile $\mathrm{Cu}$ fractions, which are more accessible and may cause toxicity to plants (CASALI et al., 2008; MIOTTO et al., 2017).

In the roots, uptake and radial transport of $\mathrm{Cu}$ can happen via the symplast, by means of specific transporters located in the plasma membrane, or by diffusion via the apoplast until finding diffusional barriers, such as the Casparian strip in the endodermis. The apoplast has charges derived from sulfuric $\left(\mathrm{R}_{-} \mathrm{SH}^{-}\right)$and carboxylic (R-COO-) groups, as well as organic compounds present in the cell wall. The $\mathrm{pH}$ can alter the charges of these groups, which can adsorb metal cations such as $\mathrm{Cu}$ and lead to compartmentalization of $\mathrm{Cu}$ in the root apoplast, preventing its transport to the shoots (YRUELA, 2009). However, $\mathrm{Cu}$ accumulation has also been observed in the symplast due to the formation of chelates with high affinity 
binding compounds such as organic acids, amino acids and peptides, such as metallothioneins (HALL, 2002). The complexed $\mathrm{Cu}$ is typically transferred to the vacuole to be compartmentalized and accumulated (YRUELA, 2009). The maintenance of $\mathrm{Cu}$ in the roots, complexed by organic molecules and/or compartmentalized in the vacuole, prevents its transport to the shoots, where $\mathrm{Cu}$ concentrations between $20-100 \mathrm{mg} \mathrm{kg}^{-1}$ may cause serious changes in metabolism (KABATA-PENDIAS, 2011).

In acidic soils with high $\mathrm{Cu}$ content, such as those of the vineyards in southern Brazil, the use of liming as a management practice may reduce Cu toxicity in plants such as black oats and grapevines (AMBROSINI et al., 2015). Liming causes the copper hydroxide increase in the soil solution by $\mathrm{pH}$ increase causes $\mathrm{Cu}$ complexation and precipitation, and increase cation exchange capacity (CEC), enhancing heavy metals adsorption (JORIS et al., 2012). In addition, liming increases calcium (Ca) and magnesium $(\mathrm{Mg})$ content in the soil, which compete with $\mathrm{Cu}$ for absorption pathways (KOPITTKE, et al., 2011), reducing $\mathrm{Cu}$ roots accumulation and shoot transport (JUANG et al., 2014). However, there are few studies in the literature demonstrating the beneficial effects of liming on black oats grown in sandy soils with high $\mathrm{Cu}$ content. The study aimed to assess the effect of liming in reducing $\mathrm{Cu}$ toxicity in black oats grown in sandy soil.

\section{MATERIALS AND METHODS}

Samples of a Typic Hapludalf (Soil Survey Staff, 2006) were collected at 0-20 cm in a grassland area adjacent to vineyards in the city of Santana do Livramento, located in the region of the Campanha Gaúcha, state of Rio Grande do Sul (RS), southern Brazil. The soil was air dried, passed through a $2 \mathrm{~mm}$ mesh sieve, and homogenized. A soil sample was subjected to chemical analysis and grain size analysis. The soil had $30 \mathrm{~g} \mathrm{~kg}^{-1}$, $61 \mathrm{gkg}^{-1}$ and $909 \mathrm{~g} \mathrm{~kg}^{-1}$ of clay, silt and sand, respectively (The Pipette method - EMBRAPA, 1997); $5.1 \mathrm{~g} \mathrm{~kg}^{-1}$ of total organic carbon (TOC) (Wet oxidation - EMBRAPA, 1997); 4.5 water $\mathrm{pH}$ (TEDESCO et al., 1995); 4.8mg $\mathrm{kg}^{-1}$ and $30.7 \mathrm{mg} \mathrm{kg}^{-1}$ of available phosphorous (P) and potassium (K), respectively (extracted by Mehlich-1 TEDESCO et al., 1995); $3.1 \mathrm{cmol} \mathrm{kg}^{-1}, 2.0 \mathrm{cmol}_{\mathrm{c}} \mathrm{kg}^{-1}$ and $1.8 \mathrm{cmol}_{\mathrm{c}} \mathrm{kg}^{-1}$ of exchangeable aluminum $(\mathrm{Al}), \mathrm{Ca}$ and $\mathrm{Mg}$, respectively (extracted by $\mathrm{KCl} 1 \mathrm{molL}^{-1}$ - TEDESCO et al., 1995); and $2.4 \mathrm{mg} \mathrm{kg}^{-1}$ of available $\mathrm{Cu}$ (EDTA extractor $0.01 \mathrm{molL}^{-1}$ - CHAIGNON et al., 2009). The rest of the reserved soil was divided into three portions, and three doses of limestone were added: $0,0.5 \mathrm{~g} \mathrm{~kg}^{-1}$ and $1.0 \mathrm{~g} \mathrm{~kg}^{-1}$ of soil -equal to $0,1.5 \mathrm{Mg} \mathrm{ha}^{-1}$ and $3.0 \mathrm{Mg}$ $\mathrm{ha}^{-1}$, respectively. For more details on soil preparation see AMBROSINI et al. (2016).
The experimental design was a randomized block with five replicates in a $2 \times 3$ factorial arrangement, i.e., two doses of $\mathrm{Cu}\left(0\right.$ to $\left.50 \mathrm{mg} \mathrm{kg}^{-1}\right)$ and three doses of limestone $\left(0,1.5\right.$, and $\left.3.0 \mathrm{Mg} \mathrm{ha}^{-1}\right)$, totaling six treatments. Plants were grown for 30 days in a controlled environment at a temperature of $25 \pm 2^{\circ} \mathrm{C}$ and a photoperiod of 16 hours of light, with photosynthetically active radiation of $200 \mu \mathrm{mol}$ of photons $\mathrm{m}^{-2} \mathrm{~s}^{-1}$. A modified HOAGLAND \&ARNON (1950) solution was added throughout the cultivation to supply the nutrients, except $\mathrm{Cu}, \mathrm{Ca}$ and $\mathrm{Mg}$. For more details on the experimental units and cultivation see AMBROSINI et al. (2016).

At the end of the cultivation period, shoots were cut close to the soil surface and the roots were separated from the soil by hand. Afterwards, the root and shoot fresh mass (FM) was determined on a precision balance. The fresh roots were separated into two parts: one was immediately stored in a freezer $\left(-20^{\circ} \mathrm{C}\right)$ for further analysis of $\mathrm{Cu}$ in the apoplast and symplast, and the other, along with the shoots of black oats, was dried in an oven with forced air at $65^{\circ} \mathrm{C}$ until constant mass. With this material, dry matter (DM) was quantified on a precision balance. Roots and shoots were ground and set aside for the analysis of the total contents of $\mathrm{Cu}, \mathrm{Ca}$ and $\mathrm{Mg}$.

In order to collect the rhizosphere and bulk soils, the acrylic plate of the rhizobox was removed and the roots were carefully separated from the soil. Roots were shaken three times and the soil that remained adhered to them was considered the rhizosphere, and it was carefully removed from the roots with a brush. The soil released from the roots during the shaking was considered bulk soil. Both were air dried, ground in a porcelain mortar and reserved.

Total contents of $\mathrm{Ca}, \mathrm{Mg}$ and $\mathrm{Cu}$ in tissues were determined according to EMBRAPA (1997). The analysis of $\mathrm{Cu}$ in the root apoplast and symplast was carried out according to CHAIGNON \& HINSINGER (2003). The $\mathrm{Cu}$ contents in the rhizosphere and bulk soil were determined by two different methods: $0.05 \mathrm{~mol} \mathrm{~L}^{-1} \mathrm{Na}_{2}$-EDTA/1.0mol L-1 ammonium acetate, pH 6.0 (CHAIGNON et al., 2009), herein called $\mathrm{Cu}-$ EDTA; and $0.01 \mathrm{~mol} \mathrm{~L}^{-1} \mathrm{CaCl}_{2}$ (NOVOZAMSKY et al., 1993), herein called $\mathrm{Cu}-\mathrm{CaCl}_{2}$. The determination of the $\mathrm{pH}$ of the rhizosphere and bulk soil was done in water, in 1:1 ratio (TEDESCO et al., 1995). The TOC content was analyzed by wet oxidation using potassium dichromate in sulfuric acid $\left(0.2 \mathrm{~mol} \mathrm{~L}^{-1}\right)$ medium, and the determination was done by titration with $0.1 \mathrm{~mol} \mathrm{~L}^{-1}$ ammonium ferrous sulfate (EMBRAPA, 1997).

Data were subjected to analysis of variance (ANOVA) and, when the F test was significant $(\mathrm{p}<0.05)$, means were compared by the Tukey test $(p<0.05)$. 
As it is a factorial design, in cases where there was interaction between factors (Table 1), only the results of the interaction were presented and discussed; in cases where the interaction was not significant (Table 1) only the results of main effects were presented and discussed.

\section{RESULTS AND DISCUSSION}

\section{Dry matter production and plant nutrient content}

The application of $50 \mathrm{mg} \mathrm{kg}^{-1} \mathrm{Cu}$ in the soil reduced dry matter production of the roots and shoots in 2.5 and 1.9 times (on average), respectively (Table 2). With regard to the root system, the plants grown in soil with the addition of $\mathrm{Cu}$ alone (no limestone) did not produce sufficient dry matter to be assessed. However, there was root growth in the treatments with liming and the addition of $\mathrm{Cu}$ and shoot dry matter production was twice as much in comparison to the treatment without liming, regardless of the corrective dose (Table 2). The toxic effects of $\mathrm{Cu}$ in black oats were minimized by the addition of 1.5 and $3.0 \mathrm{Mg} \mathrm{ha}^{-1}$ limestone. This possibly happened due to the increase in $\mathrm{pH}$ and cation exchange capacity (CEC) of the soil, reducing $\mathrm{Cu}$ availability to plants and, consequently, reducing the effects of toxicity, which allowed the growth of roots and shoots (AMBROSINI et al., 2015).

The average $\mathrm{Cu}$ content in the shoots of black oats in the treatments without addition of $\mathrm{Cu}$ was $23.2 \mathrm{mg} \mathrm{kg}^{-1}$ (Table 2), which falls within the normal range (5 to $30 \mathrm{mg} \mathrm{kg}^{-1}$ ) for most cultures (KABATA-PENDIAS, 2011). However, when black oats were grown in the treatment with the addition of $50 \mathrm{mg} \mathrm{kg}^{-1} \mathrm{Cu}$ without liming, the average $\mathrm{Cu}$ content in the shoots was $95.7 \mathrm{mg} \mathrm{kg}^{-1}$ (Table 2), which represents on average an increase of $157 \%$ in $\mathrm{Cu}$ content. Application of 1.5 to $3.0 \mathrm{Mg} \mathrm{ha}^{-1}$ limestone reduced the $\mathrm{Cu}$ content by $39 \%$ and $49 \%$ in the shoots of black oats, respectively.

In the roots, the increase of the dose of limestone did not change $\mathrm{Cu}$ content. However, in the treatment with the addition of $\mathrm{Cu}$ without liming, there was no root dry matter production and $\mathrm{Cu}$ content could not be determined (Table 2). However, in the treatments without $\mathrm{Cu}$ addition, where there was root dry matter production, $\mathrm{Cu}$ contents were on

Table 1 - Analysis of variance for the variables determined in the shoots and roots of black oats and in the rhizosphere and bulk soil, without and with the addition of copper, combined with doses of limestone.

\begin{tabular}{|c|c|c|c|c|}
\hline \multirow{3}{*}{ Variable } & \multicolumn{3}{|c|}{ 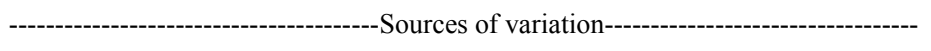 } & \multirow[t]{2}{*}{$\mathrm{CV}(\%)$} \\
\hline & $\mathrm{Cu}(\mathrm{A})$ & Limestone (B) & $A \times B$ & \\
\hline & ---------------------- & ---------------------. & ----------------------- & ----------- \\
\hline Dry matter & $324.74^{* *}$ & $20.59^{* *}$ & $1.69^{\text {ns }}$ & 12.63 \\
\hline $\mathrm{Cu}$ content & $146.59^{* *}$ & $146.59^{* *}$ & $38.68^{* *}$ & 15.42 \\
\hline \multirow[t]{3}{*}{ Ca content } & $27.89^{* *}$ & $15.91^{* *}$ & $8.81^{* *}$ & 8.52 \\
\hline & $10.52^{* *}$ & $16.28^{* *}$ & $9.39^{* *}$ & 6.92 \\
\hline & 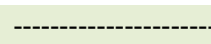 & 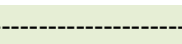 & 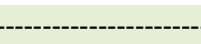 & - \\
\hline Dry matter & $24.99^{* *}$ & $1.05^{\mathrm{ns}}$ & $0.85^{\text {ns }}$ & 23.45 \\
\hline $\mathrm{Cu}$ content & $2782.34^{* *}$ & $2.31^{\mathrm{ns}}$ & $0.57^{\mathrm{ns}}$ & 8.40 \\
\hline $\mathrm{Ca}$ content & $13.05^{* *}$ & $15.88^{* *}$ & $1.26^{\mathrm{ns}}$ & 18.20 \\
\hline Mg content & $30.78^{* *}$ & $11.89^{* *}$ & $18.17^{* *}$ & 13.15 \\
\hline Apoplast $\mathrm{Cu}$ & $755.62^{* *}$ & $17.91^{* *}$ & $29.83^{\mathrm{ns}}$ & 15.59 \\
\hline \multirow[t]{2}{*}{ Symplast $\mathrm{Cu}$} & $453.72^{* *}$ & $0.81^{\mathrm{ns}}$ & $2.14^{\mathrm{ns}}$ & 14.67 \\
\hline & ----------------------. & -------------------. & soil------------------ & ----------. \\
\hline $\mathrm{pH}$ in water $(1: 1)$ & $7.81^{*}$ & $256.00^{* *}$ & $0.00^{\mathrm{ns}}$ & 21.43 \\
\hline TOC & $0.16^{\mathrm{ns}}$ & $1.96^{\mathrm{ns}}$ & $0.59^{\mathrm{ns}}$ & 14.67 \\
\hline $\mathrm{Cu}-\mathrm{CaCl}_{2}$ & $3.09^{\mathrm{ns}}$ & $0.57^{\mathrm{ns}}$ & $1.06^{\mathrm{ns}}$ & 11.21 \\
\hline \multirow[t]{2}{*}{$\mathrm{Cu}$-EDTA } & $1402.91^{* *}$ & $3.55^{\mathrm{ns}}$ & $10.01^{* *}$ & 26.71 \\
\hline & 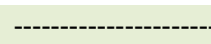 & - & 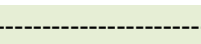 & - \\
\hline $\mathrm{pH}$ in water $(1: 1)$ & $39.49^{* *}$ & $414.57^{* *}$ & $1.62^{\mathrm{ns}}$ & 2.24 \\
\hline TOC & $0.07^{\mathrm{ns}}$ & $3.79^{\text {ns }}$ & $1.46^{\mathrm{ns}}$ & 9.97 \\
\hline $\mathrm{Cu}-\mathrm{CaCl}_{2}$ & $0.80^{\mathrm{ns}}$ & $2.85^{\mathrm{ns}}$ & $0.35^{\mathrm{ns}}$ & 16.21 \\
\hline Cu-EDTA & $1402.91^{* *}$ & $3.55^{\mathrm{ns}}$ & $10.01^{* *}$ & 17.49 \\
\hline
\end{tabular}

$\mathrm{CV}=$ coefficient of variation; $\mathrm{ns}=$ not significant; ${ }^{*}$ and ${ }^{* *}=$ significant by the $\mathrm{F}$ test at 5 and $1 \%$ probability, respectively. 
Table 2 - Dry matter and copper, calcium and magnesium contents in the shoots and roots of black oats grown in soil without and with the addition of copper combined with limestone doses.

\begin{tabular}{|c|c|c|c|c|}
\hline \multirow{3}{*}{$\mathrm{Cu}\left(\mathrm{mg} \mathrm{kg}^{-1}\right)$} & \multicolumn{3}{|c|}{ 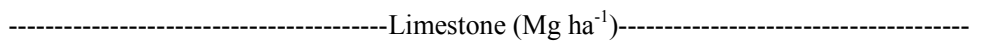 } & \multirow[t]{2}{*}{ Mean } \\
\hline & 0.0 & 1.5 & 3.0 & \\
\hline & \multicolumn{4}{|c|}{ 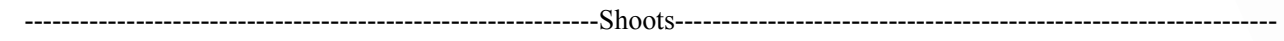 } \\
\hline & \multicolumn{4}{|c|}{ Dry matter $\left(\mathrm{g}_{\text {plant }}{ }^{-1}\right)$} \\
\hline 0 & 0.090 & 0.104 & 0.116 & $0.103 \mathrm{~A}$ \\
\hline 50 & 0.026 & 0.052 & 0.050 & $0.042 \mathrm{~B}$ \\
\hline \multirow[t]{2}{*}{ Mean } & $0.058 \mathrm{~b}$ & $0.078 \mathrm{a}$ & $0.083 \mathrm{a}$ & \\
\hline & \multicolumn{4}{|c|}{--1-- } \\
\hline 0 & $21.72 \mathrm{aB}^{(1)}$ & $27.34 \mathrm{Ab}$ & $20.6 \mathrm{aB}$ & 23.23 \\
\hline 50 & $95.74 \mathrm{aA}$ & $44.42 \mathrm{Ba}$ & $39.07 \mathrm{bA}$ & 59.74 \\
\hline \multirow[t]{2}{*}{ Mean } & 58.73 & 35.88 & 29.84 & \\
\hline & \multicolumn{4}{|c|}{ 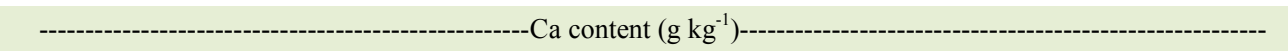 } \\
\hline 0 & $11.03 \mathrm{aB}$ & $9.56 \mathrm{Ab}$ & $10.56 \mathrm{aA}$ & 10.38 \\
\hline 50 & $15.93 \mathrm{aA}$ & $11.96 \mathrm{bA}$ & $10.66 \mathrm{bA}$ & 12.85 \\
\hline Mean & 13.48 & 10.76 & 10.61 & \\
\hline \multicolumn{5}{|c|}{ 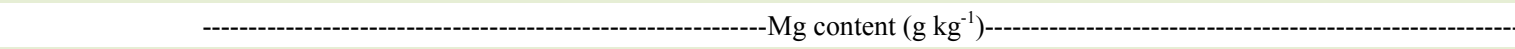 } \\
\hline 0 & $4.18 \mathrm{aB}$ & $4.02 \mathrm{aA}$ & $3.93 \mathrm{aA}$ & 4.05 \\
\hline 50 & $5.48 \mathrm{aA}$ & $3.98 \mathrm{bA}$ & $4.02 \mathrm{bA}$ & 4.49 \\
\hline \multirow[t]{3}{*}{ Mean } & 4.83 & 4.01 & 3.97 & \\
\hline & \multicolumn{4}{|c|}{ 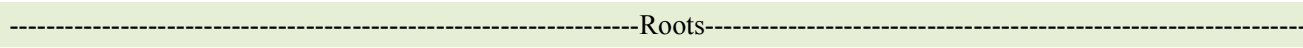 } \\
\hline & \multicolumn{4}{|c|}{ Dry matter $\left(\right.$ g plant $\left.^{-1}\right)$} \\
\hline 0 & 0.074 & 0.084 & 0.066 & $0.074 \mathrm{~A}$ \\
\hline 50 & NA & 0.042 & 0.038 & $0.040 \mathrm{~B}$ \\
\hline \multirow[t]{2}{*}{ Mean } & NA & 0.063 & 0.052 & \\
\hline & \multicolumn{4}{|c|}{ - } \\
\hline 0 & 40.88 & 16.37 & 37.83 & 31.69B \\
\hline 50 & NA & 445.70 & 454.01 & $449.85 \mathrm{~A}$ \\
\hline \multirow[t]{2}{*}{ Mean } & NA & 231.03 & 245.92 & \\
\hline & \multicolumn{4}{|c|}{ 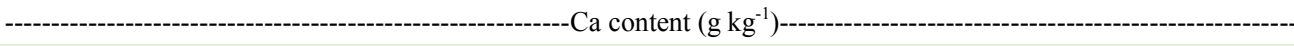 } \\
\hline 0 & 6.01 & 4.36 & 8.24 & $6.21 \mathrm{~B}$ \\
\hline 50 & NA & 6.81 & 9.40 & $8.11 \mathrm{~A}$ \\
\hline \multirow[t]{2}{*}{ Mean } & NA & $5.58 \mathrm{~b}$ & $8.82 \mathrm{a}$ & \\
\hline & \multicolumn{4}{|c|}{ 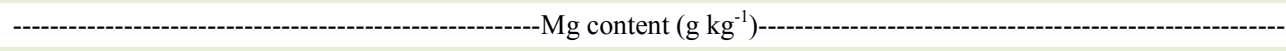 } \\
\hline 0 & $3.36 \mathrm{a}$ & $2.22 \mathrm{bA}$ & 4.19aA & $3.26 \mathrm{~A}$ \\
\hline Mean & NA & $3.26 \mathrm{~b}$ & $4.31 \mathrm{a}$ & \\
\hline
\end{tabular}

average $31.69 \mathrm{mg} \mathrm{kg}^{-1}$ (Table 2). When the black oats were subjected to the addition of $50 \mathrm{mg} \mathrm{kg}^{-1}$ of $\mathrm{Cu}$, the average $\mathrm{Cu}$ content in the roots was $449.85 \mathrm{mg} \mathrm{kg}^{-1}$ (Table 2), which represents an increase of 14 times. 
This increase in $\mathrm{Cu}$ content in the root, but not in the shoot, is due to its preferential accumulation in the root system, because of its high affinity for ligands of the root cell wall, causing low mobility within the plant (AMBROSINI et al., 2016). Accumulation in roots is an important mechanism to prevent $\mathrm{Cu}$ transport to the shoots, which in high concentrations causes oxidative damage (DALCORSO et al., 2014). However, exposure of the root system to high concentrations of $\mathrm{Cu}$ may cause damage to its structure, such as reduced cap, disorganized root apex cells and reduced root growth (AMBROSINI et al., 2015; GUIMARÃES et al., 2016).

Although, we did not carry out structural analysis on the root system in this study, root death in the treatment with the addition of $\mathrm{Cu}$ without liming indicates that excess of $\mathrm{Cu}$ presents severe damage to the formation of roots of black oats, reducing DM production, thus confirming the results obtained by GUIMARÃES et al. (2016) with the same species. This inhibitory effect of excess $\mathrm{Cu}$ on root growth may have reduced the uptake of water and nutrients by the plant and; consequently, caused a decrease in growth and shoot dry matter production of black oats (AMBROSINI et al., 2016).

Ca contents in the shoots and roots increased by 31 and $35 \%$ with $\mathrm{Cu}$ addition, respectively, except for the roots of the treatment with the highest dose of limestone. (Table 2); while, the Mg content in the shoots increased by $31 \%$ (Table 2). Increase of $\mathrm{Ca}$ and $\mathrm{Mg}$ contents by adding $\mathrm{Cu}$ was probably caused by concentration of these nutrients in the plant, since there was reduced dry matter production in these treatments (Table 2). The excessive increase of a cation in the soil, in this case $\mathrm{Cu}$, due to mass effect, makes it more competitive compared to other cations, such as $\mathrm{Ca}$ and $\mathrm{Mg}$, by the adsorption by the ligands of the root cell wall, which favors its uptake by the plant (KOPITTKE et al., 2011).

\section{Copper content in the root apoplast and symplast}

$\mathrm{Cu}$ content in the apoplast and symplast, and total $\mathrm{Cu}$ in the roots were higher in plants grown in soil with the addition of $\mathrm{Cu}$, with average increases of 36 and 14 times, respectively (Figure 1A and 1B). However, the application of $3.0 \mathrm{Mg} \mathrm{ha}^{-1}$ limestone reduced the $\mathrm{Cu}$ content in the apoplast by $36 \%$ (Figure 1A), while it did not change the $\mathrm{Cu}$ content in the symplast (Figure 1B).

The plant cell wall has $-\mathrm{COOH},-\mathrm{OH}$, and -SH groups that have affinity for divalent and trivalent cations at the $\mathrm{pH}$ commonly reported in the apoplast. These interactions occur mainly with polysaccharides rich in carboxyl groups, such as homogalacturonans (HGAs), which are part of pectins (KRZESŁOWSKA, 2010). With the increase in $\mathrm{pH}$ derived from liming, these groups are expected to exhibit lower binding capacity and; therefore, less $\mathrm{Cu}$ will be adsorbed to the wall. In addition, $\mathrm{Ca}^{2+}$ is a ligand commonly reported in pectins and; therefore, liming may result in occupying the binding sites, preventing $\mathrm{Cu}$ adsorption (KRZESŁOWSKA, 2010). The use of liming clearly decreased the $\mathrm{Cu}$ content in the apoplast (Figure 1A),

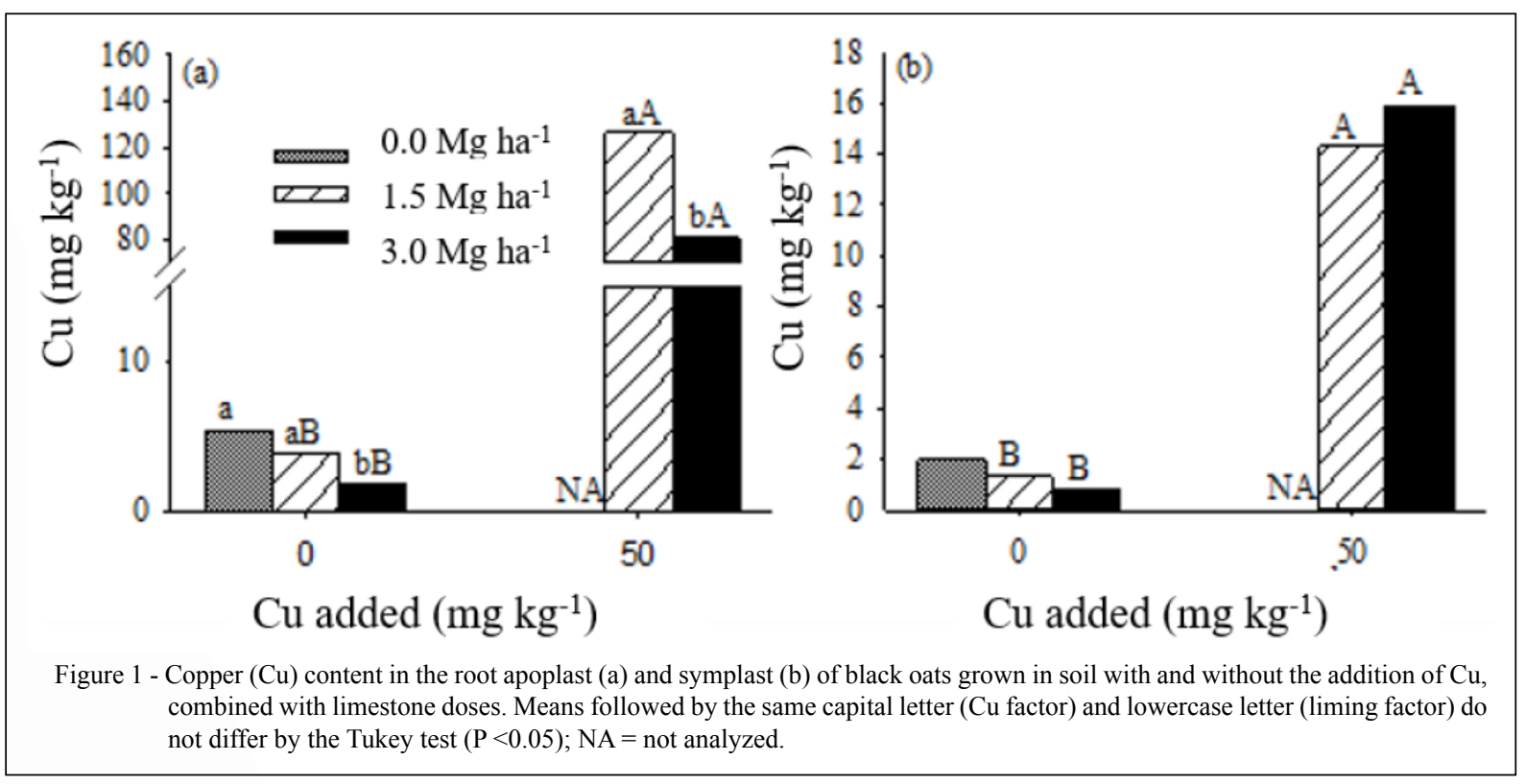

Ciência Rural, v.48, n.4, 2018. 
but no change was observed in the $\mathrm{Cu}$ content in the symplast (Figure 1B).Conversely, the increase in the dose of $\mathrm{Cu}$ significantly increased the $\mathrm{Cu}$ content in both apoplast and symplast.

\section{Soil attributes}

For the soil attributes, only $\mathrm{pH}$ values in water and $\mathrm{Cu}$ extracted by EDTA (Cu-EDTA) were influenced by treatments (Table 3). TOC and $\mathrm{Cu}$ extracted by $\mathrm{CaCl}_{2}\left(\mathrm{Cu}-\mathrm{CaCl}_{2}\right)$ were neither affected by the addition of $\mathrm{Cu}$ nor by liming. Of these attributes, $\mathrm{Cu}-\mathrm{CaCl}_{2}$ was possibly not altered because of its low values (from $0.02 \mathrm{mg} \mathrm{kg}^{-1}$ to $0.15 \mathrm{mg} \mathrm{kg}^{-1}$ ), which made detection difficult.

The $\mathrm{pH}$ in water increased with the increasing doses of limestone both in the rhizosphere and bulk soil (Table 3), which was expected. Moreover, in both, $\mathrm{pH}$ in water were lower in soil with the addition of $50 \mathrm{mg} \mathrm{kg}^{-1} \mathrm{Cu}$ compared to the soil without $\mathrm{Cu}$ addition (Table 3 ), which may have been caused by

Table 3 - Values $\mathrm{pH}$ in water, total organic carbon (TOC), copper extracted by EDTA (Cu-EDTA) and copper extracted by $\mathrm{CaCl}_{2}$ (Cu$\mathrm{CaCl}_{2}$ ) in soil without and with the addition of this metal, combined with doses of limestone.

\begin{tabular}{|c|c|c|c|c|}
\hline \multirow{3}{*}{ Copper $\left(\mathrm{mg} \mathrm{kg}^{-1}\right)$} & \multicolumn{3}{|c|}{ 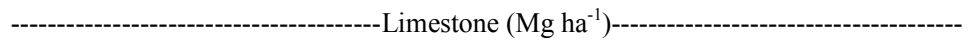 } & \multirow{3}{*}{ Mean } \\
\hline & 0 & 1.5 & 3.0 & \\
\hline & \multicolumn{3}{|c|}{ - } & \\
\hline & \multicolumn{3}{|c|}{-pH in water $(1: 1)$ - } & \\
\hline 0 & 5.08 & 6.04 & 6.85 & $6.44 \mathrm{~A}^{(1)(2)}$ \\
\hline 50 & NA & 5.74 & 6.56 & $6.15 \mathrm{~B}^{(2)}$ \\
\hline \multirow[t]{2}{*}{ Mean } & NA & $5.89 \mathrm{~b}$ & $6.70 \mathrm{a}$ & \\
\hline & \multicolumn{3}{|c|}{ - } & \\
\hline 0 & 4.70 & 5.10 & 5.03 & $5.06^{(2)}$ \\
\hline 50 & NA & 5.66 & 4.96 & $5.31^{(2)}$ \\
\hline \multirow[t]{2}{*}{ Mean } & NA & 5.37 & 4.98 & \\
\hline & \multicolumn{3}{|c|}{ - } & \\
\hline 0 & 0.02 & 0.00 & 0.00 & $0.00^{(2)}$ \\
\hline 50 & NA & 0.15 & 0.04 & $0.10^{(2)}$ \\
\hline \multirow[t]{2}{*}{ Mean } & NA & 0.08 & 0.02 & \\
\hline & \multicolumn{3}{|c|}{ - } & \\
\hline 0 & $1.89 \mathrm{~b}$ & $3.05 \mathrm{aB}$ & $2.47 \mathrm{aB}$ & $2.76 \mathrm{~B}^{(2)}$ \\
\hline 50 & NA & $32.68 \mathrm{aA}$ & $38.20 \mathrm{aA}$ & $35.44 \mathrm{~A}^{(2)}$ \\
\hline \multirow[t]{3}{*}{ Mean } & NA & 17.86 & 20.33 & \\
\hline & \multicolumn{3}{|c|}{ 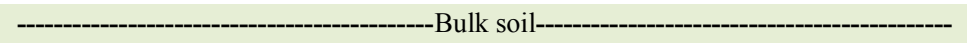 } & \\
\hline & \multicolumn{3}{|c|}{--1n in water $(1: 1)$ - } & \\
\hline 0 & 4.96 & 5.94 & 6.59 & $5.83 \mathrm{~A}$ \\
\hline 50 & 4.71 & 5.53 & 6.37 & $5.53 \mathrm{~B}$ \\
\hline \multirow[t]{2}{*}{ Mean } & $4.84 \mathrm{c}$ & $5.73 \mathrm{~b}$ & $6.48 \mathrm{a}$ & \\
\hline & \multicolumn{3}{|c|}{ 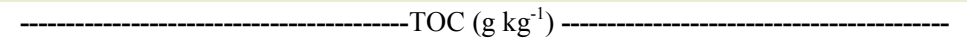 } & \\
\hline 0 & 5.33 & 5.53 & 4.66 & 5.17 \\
\hline 50 & 5.83 & 5.03 & 4.86 & 5.24 \\
\hline \multirow[t]{2}{*}{ Mean } & 5.58 & 5.28 & 4.70 & \\
\hline & \multicolumn{3}{|c|}{ - } & \\
\hline 0 & 0.04 & 0.14 & 0.10 & 0.09 \\
\hline 50 & 0.02 & 0.08 & 0.10 & 0.06 \\
\hline \multirow[t]{2}{*}{ Mean } & 0.03 & 0.11 & 0.10 & \\
\hline & \multicolumn{3}{|c|}{ - } & \\
\hline 0 & $2.03 \mathrm{aB}$ & $2.32 \mathrm{aB}$ & $2.61 \mathrm{aB}$ & $2.32 \mathrm{~B}$ \\
\hline 50 & $35.73 \mathrm{aA}$ & $36.89 \mathrm{aA}$ & $39.36 \mathrm{aA}$ & $37.33 \mathrm{~A}$ \\
\hline Mean & 18.88 & 19.61 & 20.98 & \\
\hline
\end{tabular}

${ }^{(1)}$ Means followed by the same capital letter in the column and by the same lowercase letter in the row do not differ by the Tukey test (P $<0.05$ ); NA $=$ not analyzed; ${ }^{(2)}$ Means of the doses of 1.5 and $3.0 \mathrm{Mg} \mathrm{ha}^{-1}$ limestone, as there is no rhizosphere soil in the treatment without liming and with $50 \mathrm{mg} \mathrm{kg}^{-1} \mathrm{Cu}$. 
the adsorption of $\mathrm{Cu}$ in functional groups of organic and inorganic reactive particles, and desorption of $\mathrm{H}^{+}$ ions to the soil solution (DUPLAY et al., 2014).

Rhizosphere and bulk soils with the addition of $50 \mathrm{mg} \mathrm{Cu} \mathrm{kg}^{-1}$ soil exhibited the highest $\mathrm{Cu}$ contents extracted by EDTA compared to treatments without the addition of $\mathrm{Cu}$, while the different doses of limestone did not change the $\mathrm{Cu}$ contents extracted by EDTA (Table 3). The absence of reduction in $\mathrm{Cu}$ contents in soil by the increase in limestone doses can be explained by the high correlation of the $\mathrm{Cu}$ extracted by EDTA and total $\mathrm{Cu}$ in the soil, as observed by BRUN et al. (1998), because the $\mathrm{Cu}$ extracted by EDTA is only slightly influenced by $\mathrm{pH}$ and soil CEC. Furthermore, according to these authors, the $\mathrm{Cu}$ extracted by EDTA is not always a good indicator of the amount of $\mathrm{Cu}$ uptake by plants.

Although, the soil $\mathrm{Cu}$ contents extracted by EDTA and $\mathrm{CaCl}_{2}$ did not decrease with increasing doses of limestone, the effects of liming in reducing $\mathrm{Cu}$ toxicity in black oats are clear, since the increase in doses of limestone promoted increased plant growth, resulting in more dry matter production (Table 2).

\section{CONCLUSION}

Liming reduced $\mathrm{Cu}$ toxicity in black oats and can be recommended to reduce the negative effects on sandy soils with low organic matter content. Liming with a dose of $1.5 \mathrm{Mg} \mathrm{ha}^{-1}$ limestone capable of raising soil to $\mathrm{pH} 5.5$, reduce the phytotoxic effects of $\mathrm{Cu}$ in vineyard soils with a history of copper-based fungicide application.

\section{ACKNOWLEDGEMENTS}

The authors are grateful to the Coordenação de Aperfeiçoamento de Pessoal de Nível Superior (CAPES) for granting a scholarship to the second, third and fourth authors.

\section{DECLARATION OF CONFLICT OF INTEREST}

The authors declared no potential conflicts of interest with respect to the research, authorship, and/or publication of this article.

\section{REFERENCES}

AMBROSINI, V. G., et al. Reduction of copper phytotoxicity by liming: A study of the root anatomy of young vines (Vitis labrusca L.). Plant Physiology and Biochemistry (Paris), v. 96, p. 270-280, 2015. Available from: <https://doi.org/10.1016/j.plaphy.2015.08.012>. Accessed: Jan. 17, 2017. doi: 10.1016/j.plaphy.2015.08.012.

AMBROSINI, V. G., et al. Liming As an Ameliorator of Copper Toxicity in Black Oat (Avena strigose). Journal of Plant Nutrition, v. 39, p. 00-00, 2016. Available from: $<$ https://doi.org
/10.1080/01904167.2016.1240203>. Accessed: Feb. 18, 2017. doi: 10.1080/01904167.2016.1240203.

BRUN, L. A., et al. Relationships between extractable copper, soil properties and copper uptake by wild plants in vineyard soils. Environmental Pollution. 102 (1998) 151-161. Available from: $<$ https://doi.org/10.1016/S0269-7491(98)00120-1>. Accessed: Jan. 21, 2017. doi: 10.1016/S0269-7491(98)00120-1.

CASALI, C. A., et al. Copper forms and desorption in soils under grapevine in the Serra Gaúcha of Rio Grande do Sul. Revista Brasileira de Ciencia do Solo, v. 32, n. 4, p. 1479 1487, ago. 2008. Available from: <http://dx.doi.org/10.1590/ S0100-06832008000400012>. Accessed: Mar. 17, 2017. doi: 10.1590/S0100-06832008000400012.

CHAIGNON, V et al. A Biotest for evaluating copper Bioavailability to Plants in a Contaminated Soil. Journal of Environment Quality, v. 32, n. 3, p. 824, 2003. Available from: <https://dl.sciencesocieties. org/publications/jeq/abstracts/32/3/824> . Accessed: Apr. 12, 2017. doi: $10.2134 /$ jeq2003.8240.

CHAIGNON, V., et al. Copper availability and bioavailability are controlled by rhizosphere $\mathrm{pH}$ in rape grown in an acidic $\mathrm{Cu}$-contaminated soil. Environmental Pollution, v. 157, n. 12, p. 3363-9, dez. 2009. Available from: <https://doi.org/10.1016/j.envpol.2009.06.032>. Accessed: Jan. 07, 2017. doi: 10.1016/j.envpol.2009.06.032.

DALCORSO, G., et al. Nutrient metal elements in plants. Metallomics: integrated biometal science, v. 6, n. 10, p. 1770-88, out. 2014. Available from: $<$ http://pubs.rsc.org/en/content/articlepdf/2014/ $\mathrm{mt} / \mathrm{c} 4 \mathrm{mt} 00173 \mathrm{~g}>$. Accessed: Feb. 14, 2017. doi: 10.1039/c4mt00173g.

DUPLAY, J., et al. Copper, zinc, lead and cadmium bioavailability and retention in vineyard soils: The impact of cultural practices. Geoderma, v. 230-231, p. 318-328, out. 2014. Available from: $<$ https://doi.org/10.1016/j.geoderma.2014.04.022>. Accessed: Feb. 25, 2017. doi: 10.1016/j.geoderma.2014.04.022.

EMBRAPA. Manual de métodos de análise de solo. Rio de Janeiro: EMBRAPA-CPNS, 1997. 212p. Available from: $<$ https://www.agencia.cnptia.embrapa.br/Repositorio/Manua $1+$ de+Metodos_000fzvhotqk02wx5ok0q43a0ram31wtr.pdf $>$. Accessed: Mar. 19, 2017.

GUIMARÃES, P. R., et al. Black oat (Avena strigosa Schreb.) growth and root anatomical changes in sandy soil with different copper and phosphorus concentrations. Water, Air, \& Soil Pollution, v. 227 , n. 6 , p. $1-10,2016$. Available from: $<$ https://link.springer.com/ article/10.1007/s11270-016-2900-5>. Accessed: Feb. 22, 2017. doi: $10.1007 / \mathrm{s} 11270-016-2900-5$

HALL, J. L. Cellular mechanisms for heavy metal detoxification and tolerance. Journal of Experimental Botany, v. 53, n. 366, p. 1-11, 2002. Available from: <https://www.ncbi.nlm.nih.gov/pubmed/11741035>. Accessed: Apr. 17, 2017. doi: 10.1093/jexbot/53.366.1.

HOAGLAND, D. R.; ARNON, D. I. The water-culture method for growing plants without soil. California Agricultural Experiment Station Circular, v. 347, p. 1-32, 1950.

JORIS, H. et al. Adsorção de metais pesados após calagem superficial em um Latossolo Vermelho sob sistema de plantio direto. Revista Ciência Agronômica, p. 1-10, 2012. Available from: $<\mathrm{http}: / / \mathrm{dx}$.doi.org/10.1590/ S1806-66902012000100001>. Accessed: Mar. 06, 2017. doi: 10.1590/ S1806-66902012000100001. 
JUANG, K. W. et al. Influence of magnesium on copper phytotoxicity to and accumulation and translocation in grapevines. Ecotoxicology and Environmental Safety v. 104, p. 36-42, 2014. Available from: <https:// doi.org/10.1016/j.ecoenv.2014.02.008>. Accessed: Apr. 12, 2017. doi: 10.1016/j.ecoenv.2014.02.008.

KABATA-PENDIAS, A. Trace elements in soils and plants. $4 \mathrm{o}$. ed. New York: Taylor \& Francis Group, LLC, 2011. Available from: $<$ http://base.dnsgb.com.ua/files/book/Agriculture/Soil/Trace-Elementsin-Soils-and-Plants.pdf $>$. Accessed: Apr. 03, 2017.

KOPITTKE, P. M., Et al. Alleviation of $\mathrm{Cu}$ and $\mathrm{Pb}$ rhizotoxicities in cowpea (Vigna unguiculata) as related to ion eactivities at root-cell plasma membrane surface. Environmental Science and Technology 45: 4966-4973, 2011. Available from: <https://pubs.acs.org/doi/full/10.1021/ es1041404>. Accessed: Feb. 05, 2017. doi: 10.1021/es1041404.

KRZESŁOWSKA, M. The cell wall in plant cell response to trace metals: polysaccharide remodeling and its role in defense strategy. Acta Physiol Plant, v. 33, p. 35-51, 2014. Available from: $<$ https://link.springer.com/article/10.1007/s11738-010-0581-z>. Accessed: Jan. 14, 2017. doi: 10.1007/s11738-010-0581-z.

MICHAUD, A. M. et al. Copper uptake and phytotoxicity as assessed in situ for durum wheat (Triticum turgidum durum L.) cultivated in Cu-contaminated, former vineyard soils. Plant and Soil, v. 298, n. 1-2, p. 99-111, 2007. Available from: <https://link.springer.com/ article/10.1007/s11104-007-9343-0>. Accessed: Mar. 21, 2017. doi: 10.1007/s11104-007-9343-0.

MIOTTO, A. et al. Copper Accumulation and Availability in Sandy, Acid, Vineyard Soils. Communications in soil science and plant analysis, v. 48, p. 1-7, 2017. Available from: $<$ https://doi.org/10.1080/00103624.2017.1 341908>. Accessed: Apr. 01, 2017. doi: 10.1080/00103624.2017.1341908.

NOVOZAMSKY, I., et al. A single extraction procedure of soil for evaluation of uptake of some heavy metals by plants. International Journal of Environmental Analytical Chemistry .51: 47-58. 1993. Available from: <https://doi.org/10.1080/03067319308027610>. Accessed: Feb. 18, 2017. doi: 10.1080/03067319308027610.

SOIL SURVEY STAFF. Soil Survey Staff Keys to Soil Taxonomy (tenth ed.) USDA-SCS, Washington, 2006. Available from: \https://www.nrcs.usda.gov/ Intemet/FSE_DOCUMENTS/nrcs142p2_052172.pdf $>$. Accessed: Feb. 02, 2017.

TEDESCO, M. et al. Análises de solo, plantas e outros materiais. Porto Alegre, 1995.

YRUELA, I. Copper in plants: acquisition, transport and interactions. Functional Plant Biology, v. 36, n. 5, p. 409, 2009. Available from: $<$ https://www.researchgate.net/publication/271310242_Chlorophyll_ Fluorescence_Transient_Analysis_in_Alternanthera_tenella_Colla_Plants Grown in Nutrient Solution_with_Different_Concentrations of_Copper>. Accessed: Apr. 13, 2017. doi: 10.1071/FP08288. 